\title{
И. И. Плеханова
}

\section{Иркутский государственный университет}

\section{Владимир Маяковский как социалистический примитивист}

Аннотация: Послереволюционная поэзия В. Маяковского трактуется как воплощение поэтики примитивизма: жизнеутверждающий пафос, вытеснение рефлексии, упрощённая картина мира, праздничная перспектива истории, «весомая, грубая, зримая» образность и форма стиха. Поворот от футуризма к примитивизму рассматривается как закономерное развитие принципов авангарда - от конструирования экспрессии форм к стратегии жизнестроения. Обращение к теории наивного искусства и примерам живописного примитива, а также к психологической характеристике личности поэта позволяет найти аргументы, подтверждающие статус агитационной, гражданской и эпической поэзии В. Маяковского 1920-х годов как социалистического примитивизма.

The post-revolutionary poetry of V. Mayakovsky is interpreted as an embodiment of primitivism poetics: life-asserting enthusiasm; exclusion of reflexion; simplified picture of the world; festive historical prospects; «weighty, rough and visible» imagery and form of a verse. The turn from futurism to primitivism is regarded as natural development of avant-gard principles as evolution from constructing the expression of forms to the strategy of lifebuilding. Appeal to the theory of naive art and examples of pictorial primitivism, as well as to the psychological characteristics of a poet's personality makes it possible to find arguments confirming the status of V. Mayakovsky's agitational, civil and epic poetry of the 1920 s as socialist primitivism.

Ключевые слова: В. Маяковский, теория художественного примитива, социалистический примитивизм, психология творчества, игра.

V. Mayakovsky, theory of artistic primitivism, socialist primitivism, psychology of creative work, game.

УДК 82:1; 821.161.1

Контактная информация: Иркутск, ул. Чкалова, 2. ИГУ, факультет филологии и журналистики. Тел. (3952) 243906. E-mail: oembox@yandex.ru

\section{О применении терминов «наив» и «примитивизм» к высокой литературе}

Типологическое определение послереволюционной поэзии В. Маяковского всё ещё актуально - как характеристика целостности эстетической системы и преемственности этапов развития. Вопрос в том, оставался ли поэт авангардистом в 1920-е годы и в каком эстетическом ключе следует воспринимать поэтику советского периода.

Радикальное формотворчество завершилось с переходом к агитационной поэзии, обязанной быть суггестивной, содержательно простой и внятной по образу высказывания. В антологии «Поэзия русского футуризма» (1999) подборку Маяковского венчает «Наш марш» (1918). В. А. Альфонсов во вступительной статье 
настаивал на исчерпанности сугубо авангардной модели творчества: поскольку изначально «футуризм был не только искусством - он был общественным поведением, освобождением от норм в широком масштабе», то и «должен был трансформироваться во что-то другое, перемешаться с жизнью, предстать в её формах, даже и безотносительных к искусству» [1999, с. 61]. Для самого поэта перемена самоидентификации произошла в 1923 году. Ещё накануне поэму «Пятый Интернационал» (1922) открывал «Приказ № 3» ко всем художественным силам - претензия на лидерство по праву обладания ясной, безусловной истиной: «Прочесть по всем эскадрильям // футуристов, крепостям классиков... <..> Я // поэзии // одну разрешаю форму: // краткость, // точность математических формул» [Литературные манифесты, 2001, с. 199-200]. Основание для радикализма - пророчество футуриста, прозревшего сияние «ЗеФеКа» - Земной Федерации Коммун в середине XXI века. Через год установка на творческий прагматизма потребовала организации ЛЕФа: «Футуристы!! Ваши заслуги в искусстве велики: но не думайте прожить на проценты вчерашней революционности. Работой в сегодня покажите, что наш взрыв не отчаянный вопль ущемлённой интеллигенции, а борьба работа плечом к плечу со всеми, с рвущимися к победе коммуны» («Кого предостерегает Леф?») [Там же, с. 210]. Но можно ли считать социально ангажированное творчество - агитки, сатиру, лироэпос, гражданскую, даже любовную лирику 1920-х годов - авангардной поэзией?

Советский авангард перенёс жизнестроительные амбиции в сферу идеологии, но реализованы они были в иной, традиционной поэтике: «сталинская эпоха осуществила основное требование авангарда о переходе искусства от изображения жизни к её преображению методами тотального эстетико-политического проекта» [Гройс, 2003, с. 56]. По утверждению Б. Гройса, авангард и социалистический реализм совпадают «и в мотивации, и в целях экспансии искусства в жизнь восстановить целостность Божьего мира, разрушенную вторжением техники, средствами самой техники, остановить технический и вообще исторический прогресс, поставив его под тотальный технический контроль, преодолеть время, выйти в вечное» [Там же, с. 95]. Технический контроль насаждал и нормативную эстетику, доступную восприятию масс. Но можно ли поэта-рабочего, т. е. демиурга-пролетария, творца нового чувства жизни, считать сугубо предтечей соцреализма, перелагавшим идеологемы в формулы стихотворной речи? Когда поэт заявлял: «Я себя / советским чувствую / заводом, // вырабатывающим счастье» («Домой!» 1925) [Маяковский, 1969, с. 236], - иррациональная избыточность метафорической экспрессии наивно перекрывала даже стахановские эстетические нормы.

Жизнестроительную миссию выполняло в XX веке не только идеологизированное искусство, но и примитив как переживание-выражение онтологического мифа. Архетипы актуализируются в обстоятельствах перенапряжения социальных и духовных процессов, «они всегда были источником защиты и спасения» [Юнг, 1991, с. 123]. Можно предположить, что послереволюционная поэзия Маяковского представляет собой литературную версию примитивизма, т. е. актуализацию «наивных» форм и логики мышлления для обеспечения органичной новизны творчества и витальности самих идей.

Для обоснования этой концепции необходимо соотнести миропонимание, духовные импульсы и образ мышления поэта-новатора с безыскусно простодушным мировосприятием художников-самородков, поскольку на этом материале разработана теория преемственности живописного примитива и примитивизма как профессиональной стилизации, эксплуатирующей поэтику наивной простоты в собственных целях. Перенос теории в сферу словесности осложняется тем, что художественный статус примитива как особой, т. е. самобытной в сравнении с фольклором и профессиональным искусством, культуры чрезвычайно высок в живописи, но остаётся неопределенным в словесности, где статус «третьей 
культуры» [Прокофьев, 1983, с. 8] эстетически сомнителен, ибо всё-таки тождествен неграмотности. Живопись, выражающая индивидуальное, нерефлексивное онтологическое миропонимание непосредственно, через собственную систему, помимо школ и в развитии народных изобразительных традиций, определена как «наивное искусство», а самодеятельная «наивная литература - это прозаические и поэтические опусы неумелых людей, подражающих образцам высокой словесности; они противостоят не только фольклорным и парафольклорным формам, но и текстам массовой культуры. <... . ..главный признак - наивность (следствие невладения навыками литературного мастерства, принимаемого за образец) определяется и градуируется субъективно < ..> границы наивной литературы (как и живописи) всегда спорны» [Рылёва, Балдина, 2011, с. 44].

В профессиональной литературе граница между примитивом и примитивизмом проходит между сугубо «сделанными» текстами: это или самовысказывание героя, или воспроизведение речевой модели в повествовании. Пример революционного наива - «Стих Марии Басовой» из повести Б. Лавренёва «Сорок первый» (1924): «Ленин герой наш пролетарский, // Поставим статуй твой на площаде. // Ты низвергнул дворец тот царский // И стал ногою на труде» [Лавренёв, 1977, с. 201]. Агитационный примитивизм тоже не боится косноязычия: «Мы / новая кровь / городских жил, // тело нив, // ткацикой идей / нить. (выделено мой как пример неопределённости приёма: это или эллипсис («ткацкой <фабрики> идей нить») или анаколуф (грамматическая норма «ткацкой идеи нить»)? - И. П.) // Ленин - / жил, // Ленин - / жив, // Ленин - / будет жить» («Комсомольская» 31 марта 1924) [Маяковский, 1963, с. 339]. Два пафосных выказывания разных субъектов - лирику девушки-бойца и речёвку абстрактных комсомольцев объединяет родство психологических переживаний: коллективная пролетарская самоидентификация, энергия самосознания избранных историей, отождествление собственной воли с волей вождя, заклинание будущего, эмблематичная метонимическая образность: «дворец царский»= власть самодержавия, «стал ногою на труде»= пролетариат как опора вождя; «новая кровь»= молодость, «тело нив»= рождающая почва.

Действительно, утопичность, или склонность к идеализации, - родовая черта наивного сознания. Оно целостно [Медведева, 2001, с. 277], простодушно, нерефлексивно, эмоционально и интуитивно, воплощает в творчестве «объекносубъектную слитность» [Рылёва, Балдина, 2011, с. 86], тяготеет к праздничности [Богемская, 2001a, с. 77], правдиво в отношении к миру, искренне в переживаниях и потому «разрушает опыт лицемерия культуры» [Гиренок, 2001, с. 23]. Наивный автор - визионер, фантазёр [Богемская, 2001а, с. 182], его цель - не мимесис, а жизнеутверждение, «радость, к которой стремится каждый художник-примитивист, созидающий не то, что он видит, а то, что знает и чувствует. <..> Радость, открытость миру - один из обязательных признаков наивного искусства. <..> Радость исключает обыденность» [Пименова, 2001, с. 171]. То, что удачно названо «философией наивности», раскрывает суть художественного примитива, скрытую за упрощённой формой: знаковым рисунком, отсутствием перспективы, когда цвет локален, а «предметы и люди на картине не заслоняют друг друга», ибо одинаково важны для художника [Тарабаров, 2001, с. 203]. Принципиально важно, что наивность обусловлена отнюдь не простоватостью и благодушием мастеров, а живым проявлением мифологического демиургического сознания: «через пространство мира и плоскость картины приоткрывается скрытая природа наивного искусства, его культуротворческая сила. Она не столько в способности познавать и отражать, сколько создавать иную, небывалую реальность существования человеческого Духа» [Балдина, 2001, с. 159]. Такова сугубо позитивная трактовка примитивов - наивного искусства XIX-XXI века.

Примитивизм как приём отнюдь не обусловлен счастливым сочетанием духовной цельности и спонтанности творчества, а регенерируется авангардом как 
поиск нового языка онтологической силы и безусловной выразительности. По формулировке искусствоведа, в России начала XX века он «использовался как национальное художественное арго. Обращаясь к первоосновам искусства в лубке, вывесках, детских рисунках, художники стремились утвердить цельность, незыблемость этого мощного праязыка» [Богемская, 2001б, с. 226]. Литературным аналогом признана «душевная простота» заумной поэзии В. Хлебникова, воз/сводящая «язык до первоматерии» [Рабинович, 2001, с. 53]. Идея всеединства в её натурфилософском выражении стала органичным мостом между примитивом и литературным примитивизмом в прозе А. Платонова. Её язык и особенности психологизма - «возможности перехода коллективного в личностное, пересечение границ фундаментального и конкретного» - позволяют культурологу практически идентифицировать литературных персонажей и самобытных художников: «Фактически судьбы и сущностные характеристики героев А. Платонова почти полностью совпадают с судьбами и философией классиков нашего отечественного наива - Елены Волковой, Павла Леонова, Екатерины Медведевой, Василия Романенкова, соединивших в своей пластике христианские и социалистические утопии» [Пацюков, 2001, с. 39]. Но вопрос о степени сближения наива и авторской художественной философии остаётся дискуссионным. По мнению Д. Давыдова, А. Платонов, напротив, «с максимальной резкостью обозначил внутреннюю оппозицию примитива и примитивизма в собственном творчестве и культурном поведении» [Давыдов, 2004]. Возможность определения автора как примитивиста обусловлена не только абсолютной искренностью, но и внутренними противоречиями в сознании художника, их глубиной и степенью их отрефлексированности, тогда как примитив в принципе анти- и надрефлексивен.

Исследования русского литературного примитивизма имеют уже достаточно обширную библиографию, история прослеживается со стихов капитана Лебядкина до московского концептуализма и Андрея Родионова [Там же]. Общая тенденция - подчёркнутость приёма, т. е. использование наива как маски, как средства выражения оппозиции господствующей эстетике: «В рамках русской неофициальной, андеграундной литературы 50-90 гг. примитивизм оказался одним из самых востребованных творческих методов (стоит перечислить таких его адептов, как Евгений Кропивицкий, Игорь Холин, Эдуард Лимонов, Владимир Уфлянд, Владлен Гаврильчик, Олег Григорьев, Герман Лукомников)» [Давыдов, 2001, c. 123]. В постмодернистский период приём работает как образ лирического ёрничества и игры в «новую искренность». Черты поэтики - игра в графоманство и «безыскусность» стиха, «нарочито “простые” тексты», «плохой» стиль, «“сращивание” маски и авторского голоса», многописание, «сознательная недоделанность текстов» [Давыдов, 2000]. Остраняющий абсурд «Столбцов» Н. Заболоцкого и обэриутов утратил мистериальное содержание и редуцировался до экзистенциального в школе Лианозово и в интеллектуальной деконструкции, т. е. постмодернистской иронии.

В. Маяковский не упоминается в ряду литературных примитивистов: ни среди авангардистов, ни в контексте советской культуры - среди тех, кто персонифицировал «не столько путь личности в массу... а возможности перехода коллективного в личное» [Пацюков, 2001, с. 39]. Очевидно, для исследователей примитивизма поэт не стоит в ряду тех, кто, отрекаясь от личного, реализовал «перспективы архаического художественного мышления» [Там же], как и не принадлежал к имитаторам наивной веры. Но даже обращение к очевидным примерам - агитки «Окон РОСТА» с плакатной образностью и текстом, площадная драма «Мистерия-буфф. Героическое, эпическое и сатирическое изображение нашей эпохи» $(1918,1921)$, футуристическая былина «150 000000 . Поэма» (1919март 1920) - уже даёт основание для трактовки этой поэзии как советского наива. 


\section{Маяковский-примитивист - contra et pro}

Доказательное отнесение Маяковского к примитивистам предполагает не только актуализацию соответствующих признаков поэтики, но и выявление психологической подоплёки именно таких решений: художественный примитивизм, духовно родственный непосредственному наиву, может быть только искренним поступком, деянием, а не искусной имитацией стиля. В данном случае - это безусловное приятие всей революции.

Признанию поэта как творца социалистического наива прежде всего мешает канонизированность «лучшего и талантливейшего поэта нашей советской эпохи», бронзовая монументальность рупора государственной идеологии и печать яркой индивидуальности на любом тексте, даже самом мифопоэтическом и «деперсонализированном». Таким псевдоотречением от авторства начинается поэма, которую, по замыслу творца нового «эпоса революции», мог продолжить каждый: «150 000000 мастера этой поэмы имя. // Пуля - ритм. / Рифма - огонь из здания в здание. / 150000000 говорят губами моими. // Ротаџионкой шагов / в булыжном верже площадей / напечатано это издание. <...> Кто назовёт земли гениального автора? // Так / и этой / моей / поэмы / никто не сочинитель. // И идея одна у неё - / сиять в настающее завтра» [Маяковский, 1963, с. 468]. Признать творца генерального стиля эпохи простодушным «наивом» - значит изменить содержание и духовный масштаб самой наивности, вывести вдохновенную идею за пределы социальной догмы в саму природу (в естество). Причём это природа всеобъемлющая: внутренняя (глубины сознания) и внешняя (универсум). Теория настаивает, что наив остаётся «универсальным свойством каждой личности» [Рылёва, 2011, с. 45], в случае Маяковского речь идёт уже о социально-космическом наполнении архетипического первообраза. Так, персонификация революционного народа - как тела первочеловека - отождествляет его с пространством: «Россия / вся / единый Иван, // и рука / у него - / Нева, // а пятки - каспийские степи» [Маяковский, 1963, с. 480], а в противоборстве президента Вильсона с Иваном (буржуазии с народом) участвует живая природа, техника и весь космос: «К бобрам - / арабский скакун, // к блузам - / тяжёлые туши битюжьи. <...> К бобрам / изящный ушёл лимузин, // к блузам / стал / стосильный грузовоз. <..> К бобрам становитесь, / генералы созвездья, // к блузам - / миллионы Млечного Пути» [Маяковский, 1963, с. 500-501]. Показательна эмблематическая поляризация конфликта без описания взаимодействия всех этих сил - так художник-примитивист разворачивает на живописном полотне фантастическую картину вполне материального, узнаваемого, но чудесного мира.

Аналог героического эпоса Маяковского - мирные полотна наивного художника П. Леонова (1920-2011). Они написаны в 90-е годы и не могут иллюстрировать «чемпионат / всемирной классовой борьбы!» [Маяковский, 1963, с. 501], но демонстрируют тот же принцип целостного видения мира: включённость в социальную жизнь всей природы, когда по народной тропе к памятнику Ленину шествуют не только люди и всадники, но верблюд и медведь, а вертикаль живого космоса представлена птицами. В картине «Спорт» (1998) параллельно празднику с участием животных и машин неожиданно разворачивается батальная тема с жёстко разделёнными флангами - красочной Красной Армией и чёрной фашистской силой. Мысли П. Леонова об искусстве поразительно созвучны эстетике радостного жизнеутверждения и обусловлены не конъюнктурой, а осознанным призванием: «Художник должен быть пропагандистом и агитатором, изобретателем и проектировщиком. И находиться во главе передового общества, что и являлось бы гордостью России. Наносить на полотно лучшие идеи и распространять их среди народных масс. < ..> Художник не должен рисовать лишь бы рисовать. Его надо спасти от опасного натурализма. Художники наносили быт народа и трудовую деятельность. Например, картина Репина "Бурлаки на Волге” или Сурикова “Боярыня Морозова”. Надо рисовать художника на рабочем месте как портрет 
художника Шишкина в шляпе и в оригинальном костюме. Ведь Ломоносов и то надел парик, а не делал из себя карикатуру. Посмотрите на портреты членов Политбюро. Черненко, ему 70 лет, а на портрете ему лет 25. Поэтому каждого ученика, посещающего художественную школу, надо учить, как рисовать, что надо переделывать, т. е. украшать, переконструировать. И нужно делать в лучшую сторону. $<\ldots>$ Деньги можно приобретать разным способом. Но это не подвиг и не героизм. И для народа нет никакой радости» (17 февраля 1996) [Павел Леонов..., 2001 , с. 189]. Общий «дискурс» несёт отпечаток идеологии, от которой сам художник пострадал в полной мере, но установка «украшать и переконструировать», чтобы образ соответствовал мечте, а не реальности, - принцип наива, а не соцреализма.

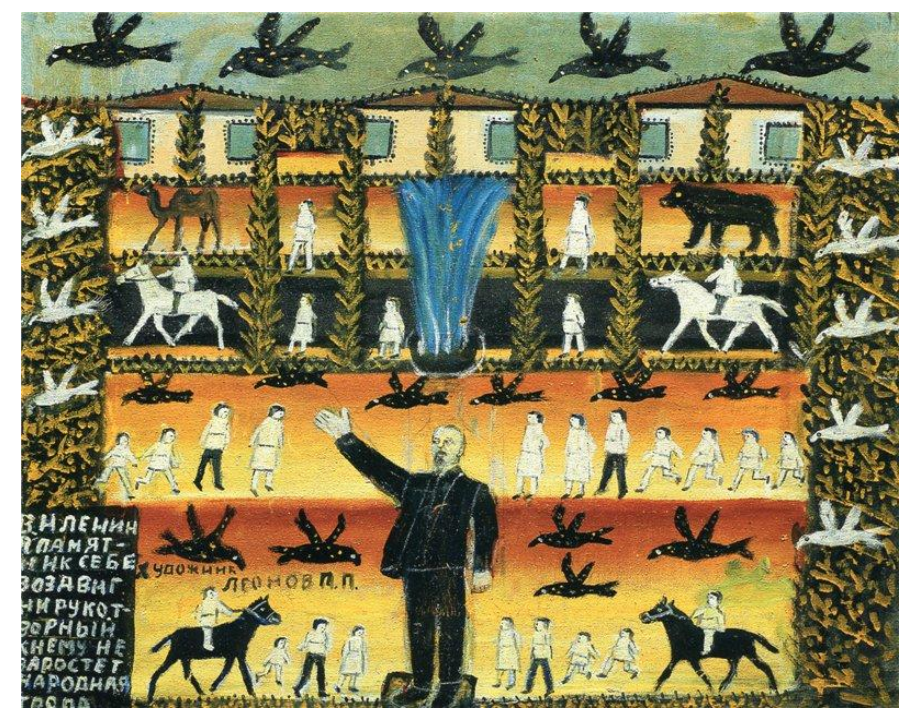

В. И. Ленин. Я памятник себе воздвиг нирукотворный кнему не заростёт народная тропа. Художник Леонов П. П. (Прим. Название и подпись автора).

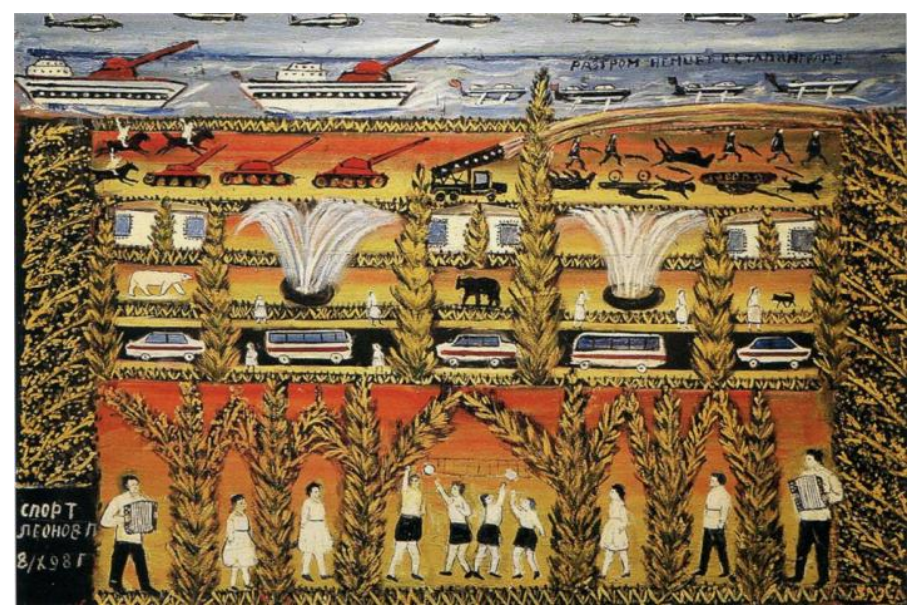

П. Леонов. Спорт. 8/Х 98 г. (на дальнем плане представлена память о войне и надпись «Разгром немцев в Сталинграде») http://koroleni.livejournal.com/205777.html 
Цель наива - гармония, умиротворение, «возвращение в Эдем»: «солгать не может человек-творящий-впервые-бытие в одном шаге от Рая» [Рылёва, 2011, c. 49]. Маяковский - поэт первотворения, и он венчает все послереволюционные эпические полотна образом феерического великолепия, «о рае сегодняшнем раструбливая весть» [Маяковский, 1963, с. 513]. Финал поэмы «Владимир Ильич Ленин» (1924) - апофеоз бессмертия вождя, итог «Хорошо!» (1927) не только в том, что «Радость прёт. <...> Жизнь прекрасна / и / удивительна» [Маяковский, 1969, с. 599], это и библейская реминисценция: «И увидел Бог всё, что Он создал, и вот, хорошо весьма» (Быт. 1: 31). Присутствие всепримиряющей перспективы принципиально значимо для разрешения одного из главных препятствий при определении Маяковского как примитивиста - категоричности, воинственности и готовности принять насилие. Поэт не уставал заявлять, что «кровожадность» футуристов - только средство экспрессии, художественная условность. Так гиперболическая беспощадность - «отца - // предложи на старьё меняться, - // мы // и его // обольём керосином // и в улицы пустим - // для иллюминаций» («Той стороне» Декабрь 1918) [Маяковский, 1963, с. 253] - лишь перифразированная пословица «Ради красного словца не пожалеешь и отца». Апофеоз декларации вполне гуманистический: «Мы смерть зовём рожденья во имя. <..> Когда ж// прорвёмся сквозь заставы // и праздник будет за болью боя, - // мы // все украшенья // расставить заставим - // любите любое!» [Маяковский, 1963, с. 254-255]. Владей поэтом ярая пролетарская ненависть, вряд ли бы в «Хорошо!» появилась пронзительная картина прощания барона Врангеля с Россией: «И над белым тленом, // как от пули падающий, // на оба / колена // упал главнокомандующий. // Трижды / землю / поцеловавши, // трижды / город / перекрестил» [Маяковский, 1969, с. 583]. Наив выше злобы дня. Так, П. Леонов с одинаковым вдохновением писал картины «Божья мать приглашает ангелов на совещание», «Отряд Котовского в укрытии» и двойной портрет «Император Николай II Александрович. Императрица Александра Фёдоровна». Наив не эклектичен, а синкретичен и представляет мифы коллективного, а не классового сознания.

Именно так - как «первого в мире поэта масс» («Эпос и лирика современной России» 1932) [Цветаева, 1991, с. 294] - понимала Маяковского М. Цветаева, подчёркивая его чуткость: «Заказ множества Маяковскому: скажи нас» («Поэт и время» 1932) [Там же, с. 68]. Голос масс сродни стихии - это следует из ответа Цветаевой на собственный вопрос, «какова же стихия, каков же демон, вселившийся в тот час в Маяковского и заставивший его написать Врангеля»: «Не Белое движение, а Чёрное море, в которое, трижды поцеловав русскую землю, ступил Главнокомандующий» («Искусство при свете совести» 1932) [Там же, с. 95]. То, что исследователи называют коллективным подсознанием, рационализируется поэтами как воля природы, и это прямо относится к вопросу об особой экспрессии насилия, свойственной стихам Маяковского, но не истинному примитиву. Непосредственные отклики самобытных художников на кровь и ужасы Гражданской войны нами не найдены (в фильме «В огне брода нет» (1967) рисунки наивной художницы Тани Тёткиной, героизирующие Красную Армию, выполнены художником Н. Васильевой и созвучны стихам Марютки из повести «Сорок первый»). Плакатная стилистика агиток из «Окон РОСТА» тяготеет к лубку, в котором картинки насилия не страшные, а смешные: «3. Паны красным ткут петлю, // нам могилу роют. // 4. Ссыпь в могилу эту тлю / вместе с Петлюрою!» («Мчит Пилсудский...» Апрель 1920) [Маяковский, 1963, с. 270]. Настоящей яростью дышат строки, обвиняющие всех, кто сыт и не сочувствует голоду 1921 года, от буржуазии до всей русской эмиграции, которой приписано злорадство: «Будьте прокляты! // Вечное “вон!” им! // Всех отвращая иудьим видом, // французского золота преследуемые звоном, // скитайтесь чужбинами Вечным жидом! // Леса российские, // соберитесь все! // Выберите по самой большой осине, // чтоб образ ихний // вечно висел, // под самым небом качался, синий» («Сволочи!» 1922) [Маяков- 
ский, 1963, с. 301]. Инвектива напечатана в «Известиях» в рамках кампании, возлагающей всю ответственность за бедствие на внешнего врага; так выразительность и сила искренних строк доверчивого Маяковского служили политике, буквальной злобе дня.

На примитив принято смотреть с умилением - как на голос божьей простоты, но Г. Гачев задался вопросом: «а может ли Зло быть наивным?» [2001, с. 32]. Вопрос решается не онтологически, а психологически - как ограниченность органичного, как следствие самососредоточенности яркой индивидуальности, ибо «наивняк - слепец, нарциссичен, субъективен: монологичен, слышит лишь себя... Так что наивняк, как голос Натуры прямой, может вступать в конфликт с Культурой. И Натура = Дура тут - такою оборачивается» [Там же, с. 33]. Начало наивного зла - гнев Каина: он убил брата, «тогда как причина - БОГ, кто почему-то не принял его жертвы... Так что субстанция ЗЛА - глупость, незнание» [Там же, c. 34]. Г. Гачев философски оценивал болезненные издержки наивного незнания, ибо оно не только яркое упрощение картины мира, но и неизбежное условие творчества: «Так что каждое существо - тутовый червь-шелкопряд или поэтгений - тянет в наивности, что это дело имеет со-смысл с Целым, свою нить, и в итоге создаётся множественная пёстрая ткань бытия» [Там же]. Рассуждения Г. Гачева обеспечивают взвешенное решение парадокса Маяковского - ограниченности претендента на роль не просто гения, но творца нового человека, культуры, всей жизни. Это парадокс не только личности, доверчивой и категоричной, внушаемой и амбициозной, но и всего авангарда - претензия на насильственную переделку миропонимания, мышления, существования: «А мы // не деревообделочники разве? // Голов людских обделываем дубы. <...> Но труд поэтов - почтенный паче - // людей живых ловить, а не рыб. <..> Мозги шлифуем рашпилем языка. <... Пролетарии тела и духа. // Лишь вместе // вселенную мы разукрасим // и маршами пустим ухать. // Отгородимся от бурь словесным молом. // К делу!» («Поэт рабочий» Декабрь 1918) [Маяковский, 1963, с. 252]. Эгоцентричное противоречие в самой природе авангарда: присвоив абсолютное право на Творение, он верит в безусловную силу слова, которое - не Логос, а сгусток энергии и инструмент в руках мастера. Эта авангардистская идея оставалась стержнем всего творчества поэта - до и после революции.

Притязания наивного художника тоже не знают границ. П. Леонов настаивал: «...Я ведь изобретатель. Ещё в 1944 году я уже изобретал двигатель “перпету мобиля" для угольной промышленности, врубовые машины для асбестовой промышленности, сортовки, фильтры, схему комбината. А ведь сюжет составить это надо видеть» (14 июня 1991 год) [Павел Леонов..., 1991, с. 190]. Так же доверчиво рисуется перспектива истории - апофеоз оптимизма переживается как раз накануне её крушения: «Три года побудут, а там коммунизм и мы будем жить богато, работать по способности, получать по потребности» (7 августа 1991 год) [Там же]. Суть не только в простоте 70-летнего художника, а в уверенности, что он знает правду жизни и остаётся её выразителем: «...Мои картины являются поучительной школой для проектировщиков, и книжку можно делать из одних моих картинок» (12 апреля 1994 год) [Там же, с. 191]. Наивность Маяковского поначалу буквально мессианская: знаменитый вызов «Я люблю смотреть, как умирают дети» раскрывается как «самолюбование», т. е. добровольное самораспятие поэта дитя Солнца и заместителя сбежавшего Христа - «на ржавом кресте колокольни!» («Я. 4. Несколько слов обо мне самом» 1913) [Маяковский, 1963, с. 76-77]. Но идеология революции требовала не искупительной, а самоотверженной жертвы - вдохновенного смирения собственной песни, которое на деле было отнюдь не смирением поэтической воли, а обретением себя в новой теме, открытием новой энергии творчества.

Отличие поэта-примитивиста от наивного художника в том, что он пишет не по наитию, а, зная силу слов, сам производит и красоту, и трагизм, и любые 
смыслы: «Я, // златоустейший, // чьё каждое слово // душу новородит, // именинит тело...» («Облако в штанах» Начало 1914 - июль 1915) [Маяковский, 1963, c. 160]. Нигилизм Маяковского-футуриста, оправданием которого была новая формула красоты - «радуга судорог» («Флейта-позвоночник» 1915) [Там же, c. 180], был исчерпан вместе с отрицанием онтологии во всех дореволюционных поэмах. Жизнестроительная миссия - как переход от дионисийства [Давыдов, 2006] «крикогубого Заратустры» к аполлоническому диалогу с солнцем («Необычайное приключение, бывшее с Владимиром Маяковским летом на даче» Июнь июль 1920) - требовала витальной поэтики. Собственная характеристика новой образности: «Мой стих / трудом / громаду лет прорвёт / и явится / весомо, / грубо, / зримо» («Во весь голос. Первое вступление в поэму» Декабрь 1929 г. - январь 1930 г.) [Маяковский, 1969, с. 602] - точное описание принципов примитивизма. Так показано начало революции: «Дул, / как всегда, / октябрь / ветра́ми, // как дуют / при капитализме. // За Троицкой / дули / авто и трамы, // обычные / рельсы / вызмеив. // Под мостом / Нева-река, // по Неве / плывут кронштадтцы... // От винтовок говорка // скоро / Зимнему шататься» («Хорошо!» 1927) [Там же, с. 539]. Яркая, но не агрессивная палитра, чёткий, внятный, несмотря на новизну, стих, ясность эмблематических образов, предметность мира, многофигурность, многоплановость, нарративность - общие черты поэтики октябрьских поэм и классики живописного наива.

Но, как известно, радикальное опрощение советского Маяковского виделось как творческое самоубийство [Цветаева, 1991, с. 102]. Так понимали миссию агитатора современники: «А сзади, в зареве легенд, // Идеалист-интеллигент // Печатал и писал плакаты // Про радость своего заката» («Высокая болезнь», 1923, 1928) [Пастернак, 1990, с. 241]. Так нетоварищи потомки обвиняли горланаглаваря в уже не художественной примитивности, воспринимая его мир как «конечный, упрощённый, ограниченный внешней стороной явлений, оболочкой предметов и поверхностью слов» (подчёркнуто автором. - И. П.) [Карабчиевский, 1990, с. 20]. Действительно, мажорный финал «Хорошо!» неубедителен для рефлектирующего сознания: «Радость прёт. / Не для вас / уделить ли нам?! // Жизнь прекрасна / и / удивительна. // Лет до ста́ / расти // нам / без старости. // Год от года / расти // нашей бодрости. // Славьте, / молот / и стих, // землю молодости» [Маяковский, 1969, с. 539]. Сказано грубо, но ярко, вбито «молотом» ритма и рифмы, акцентирована замена в гербе «стихом» серпа (со всеми его нежелательными коннотациями) - энергия витальности обеспечивает идее вечной жизни здешнюю основу.

Обе жертвы - самораспятие и самоотречение: «поэт / вылизывал / чахоткины плевки // шершавым языком плаката» («Во весь голос») [Там же, с. 605] - это сугубо риторические поэтические фигуры, призванные подтвердить трагический статус творца, что чуждо природному наиву. Жизнетворчество ценой жертвы собственным «Я» и запечатление жизни как исполнение собственного призвания самое радикальное расхождение в мироощущении и в поэтике революционного и органического примитива.

Но состоялась ли жертва собственной личностью в повороте от футуризма к идее соцстроительства? Советская поэзия Маяковского - продолжение творческой экспансии модернизма в жизнь и способ самоутверждения поэта с изначальными мессианскими амбициями: «И чувствую - // “я” // для меня мало́. // Кто-то из меня вырывается упрямо» («Облако в штанах») [Маяковский, 1963, с. 155-156]. Самоотречение невозможно по внутренним причинам - это было бы творческим самоубийством: «Как же // себя мне не петь, // если весь я - // сплошная невидаль» («Человек» 1916-1917) [Там же, с. 217]. Но парадокс в том, что сверхдерзкая новизна оттеняется странной интеллектуальной инертностью - открытие эксплуатируется, сюжеты дореволюционных поэм повторяются: явление небывалого поэта - конфликт со всем злом и ложью мира - представление себя искупительной 
жертвой. Христоподобие подсказано авторитетным образом той культуры, которая отрицается. Для выхода из кризиса самоповторяемости нужно было обновить содержание своего «Я» - и революция случилась как нельзя кстати, предложив мощное чувство жизни, «где каплей / льёшься с массами» («Хорошо!») [Маяковский, 1969, с. 580]. Это дало импульс развитию творчества и проявило изначальную склонность к примитиву.

Характерологический очерк, составленный нейропсихологами на материале биографическом и творческом, свидетельствует в пользу такой предрасположенности: «При всей глубине, интенсивности, безудержности своих эмоций и аффектов М. был элементарен и, если можно так выразиться, примитивен во всех своих проявлениях. Его действия, чувствования определённы, непосредственны, носят на себе печать прямоты, искренности. М. совершенно не был способен к лицемерию, обману, фальши, хитрости, задним мыслям или хитроумным комбинациям. $<\ldots>$ В полном соответствии с этим мышление М. имеет чрезвычайно конкретный, образный, если можно выразиться, предметный характер. Способность к абстракциям была несвойственна М.» [Спивак, 2001, с. 420]. Объективный анализ личности поэта позволяет заключить, что по существу после 1917 года ничего не изменилось: «М. был ярко выраженным индивидуалистом. Этот индивидуализм у М. берёт начало в сильных эмоционально-аффектных импульсах его личности. Не будучи в состоянии подавлять эти импульсы высшими сознательноволевыми задерживающими аппаратами, М. не выносил над собой также никакого постороннего контроля. Как особенно характерный пример можно привести ответ М. на вопрос о том, почему он не в партии: “А вдруг пошлют на хлебозаготовки?” (Брик)» [Там же, с. 426-427]. Соответственно коллективистская идеология сама по себе не только не вела к самоотречению, но развивала самосознание избранности, обеспечивая успех реализации: «Основные интересы М., как творческие, так и личные, шли по линии социальной. $<\ldots>$ Однако и в своём общении с коллективом М. чувствует свою связь с ним только тогда, когда он противопоставляет своё “я” коллективу, как это имеет место, когда он выступает как поэт и трибун. Вне этого противопоставления коллектив как совокупность отдельных человеческих личностей перестаёт существовать для М.» [Там же, с. 424-425]. Отсюда следует, что коллектив, которому служил поэт, был сугубо символическим «мы», отождествление с «мы» переживалось как прорыв к свободе в истории и творчестве, а объективная жизнь виделась как оправдание искренней мечты. И здесь - в порыве к неведомой свободе - поэт резонировал с наивными «чаяниями масс».

Итак, сущее в совпадении примитивиста Маяковского с наивным мироощущением, стоявшим за упрощенной, но яркой поэтикой, - энергия дерзкой отчаянной молодости, духовный импульс отождествления себя с жизненным порывом, бесстрашие доверчивой безответственности и убеждённость в оправданности времени, истории, существования.

\section{Выводы}

Не всё творчество Маяковского советского периода можно квалифицировать как примитивизм. Критерий - ясность формы и нерефлексивность авторской позиции, социальный жизнеутверждающий пафос. За пределами - поэма-фантасмагория «Про это» (1923), с трудом увенчанная призывом к новой семейной идиллии, диалоги как изживание вынужденного отчуждения («Тамара и Демон» 1924, «Разговор с фининспектором о поэзии» 1926, «Сергею Есенину» 1926), драматичная интимная лирика - всё, что отмечено самоиронией, надрывом, форсированным трагизмом, суицидальными мотивами. Двойной регистр творческого и личного существования - жизнестроительный и болезненный - свидетельствует, что новая художественная система, разрабатываемая поэтом, была большой игрой, серьёзной и азартной, и правила, по которым она строилась, соответствовали ар- 
хетипической матрице примитива как представления хода событий в их безусловной правоте. Психологи констатировали, что «М. был страстным игроком», и видели в этом «недостаточность сознательно-волевой задержки»: «М. мог играть в какой угодно обстановке и во что угодно вплоть до того, что играл в чёт и нечет на номера проходящих трамваев» [Спивак, 2001, с. 413-414]. Страсть не могла обойти творчество.

Игра поэта с неустойчивой нервной системой в эпическое жизнеутверждение была органичной потребностью и воспринималась как игра на стороне времени. Но мыслимое поэтом пересоздание истории было по существу вечным возвращением в праздник общего бытия праведников нового, очищенного от скверны мира. Логика примитива как образа мышления состоит в приятии и воссоздании не реального, а идеального образа мира. Убеждённость в абсолютной правоте своей мечты освобождала от сомнений, разрушение мечты, напротив, подрывало волю к существованию и поэта, и человека. Наивные художники отличаются творческим долголетием, их внутренний мир резонирует с природой, в которую вписан человек и история, но природа сама по себе никогда не интересовала Маяковского [Там же, с. 436], миропорядок заменяла цивилизация, а стихию - революция. Так видится океан: «Вовек / твой грохот / удержит ухо. // В глаза / тебя / опрокинуть рад. // По шири, / по делу, / по крови, / по духу - // моей революции / старший брат» («Атлантический океан» 1925) [Маяковский, 1969, с. 176]. Опора на неустойчивую субстанцию, тем более на изменчивый процесс, для человека и художника конкретного, хотя и образного мышления не обеспечивает надёжность и ясное будущее.

Примитивизм В. Маяковского можно определить как социалистический в полном соответствии с символом веры поэта: «пускай нам / общим памятником будет // построенный / в боях / социализм» («Во весь голос») [Маяковский, 1969, c. 605]. Он воспроизводил миф социализма, который совпадал в главных своих основаниях с идеологией государства: оправдание классовой борьбы, освещение конфликтов настоящего в свете утопического будущего, ускорение истории, коллективизм, строительство молодой республики. Но, в отличие от не принятого ещё в 20-х годах официально социалистического реализма, эстетика Маяковского персонифицирована, он опирался не на догму, а на самость: именно себя поэт видел человеком грядущих лет, всерьёз сопротивляясь «троглодитским» пережиткам («Про это») и выстраивая образ посредника времён и пророка социализма. Такой же автономностью отмечено сознание наивного художника. «Опрощение» Маяковского было не самоотречением и самообманом - оно было попыткой обрести позитивную онтологию не в судорожном, как в футуризме, но в радостном слове и маршевом ритме стиха, распорядителем которых оставался сам художник.

\section{Литература}

Альфонсов В. Н. Поэзия русского футуризма // Поэзия русского футуризма / Сост. В. Н. Альфонсов, С. Р. Красицкий. СПб.: Академ. проект, 1999. С. 5-66.

Балдина О. «Пространство мира и пространство картины» наивного художника (к постановке проблемы) // Философия наивности / Сост. А. С. Мигунов. М.: Изд-во МГУ, 2001. С. 149-160.

Богемская К. Наивное искусство: таланты и поклонники // Философия наивности / Сост. А. С. Мигунов. М.: Изд-во МГУ, 2001а. С. 222-234.

Богемская К. Г. Понять примитив. Самодеятельное, наивное и аутсайдерское искусство в ХХ веке. СПб.: Алетейя, 2001б. 185 с.

Гачев Г. Плюсы и минусы наивного философствования // Философия наивности / Сост. А. С. Мигунов. М.: Изд-во МГУ, 2001. С. 29-35.

Гиренок Ф. Археография наивности // Философия наивности / Сост. А. С. Мигунов. М.: Изд-во МГУ, 2001. С. 23-28. 
Гройс Б. Русский авангард: прыжок через прогресс // Гройс Б. Искусство утопии. М.: Худож. журн., 2003. С. 33-97.

Давыдов Д. От примитива к примитивизму и наоборот (русская наивная поэзия XX в.) // Арион. 2000. № 4. URL: http://magazines.russ.ru/arion/2000/4/davydovpr.html (дата обращения 10.04.2014).

Давыдов Д. Концептуальный примитивизм и «наивная концептуальность» // Философия наивности / Сост. А. С. Мигунов. М.: Изд-во МГУ, 2001. С. 122-126.

Давыдов Д. М. Русская наивная и примитивистская поэзия: генезис, эволюция, поэтика: Автореф. дис. ... канд. филол. наук. 2004. URL: http://www. dissercat.com/content/russkaya-naivnaya-i-primitivistskaya-poeziya-genezis-evolyutsiya-poetika (дата обращения 10.04.2014).

Давыдов Т. В. Дионисийское начало в ранней лирике В. В. Маяковского: Автореф. дис. ... канд. филол. наук. 2006. URL: http://www.dissercat.com/content/ dionisiiskoe-nachalo-v-rannei-lirike-vv-mayakovskogo (дата обращения 10.04.2014).

Карабчиевский Ю. Воскресение Маяковского. М.: Сов. писатель, 1990. 222 с. $320 \mathrm{c}$.

Лавренёв Б. Сорок первый. Повести. Иркутск: Вост.-Сиб. кн. изд-во, 1977.

Литературные манифесты: от символизма до «Октября» / Сост. Н. Л. Бродский, Н. П. Сидоров. М.: Аграф, 2001. 384 с.

Маяковский В. В. Избр. произведения: В 2 т. Л.: Сов. писатель, 1963. Т. 1. $667 \mathrm{c}$.

Маяковский В. В. Стихотворения. Поэмы. Пьесы. М.: Худож. лит., 1969. $735 \mathrm{c}$.

Медведева Л. Гармония мира в наивном искусстве // Философия наивности / Сост. А. С. Мигунов. М.: Изд-во МГУ, 2001. С. 276-280.

Павел Леонов о своей жизни в искусстве // Философия наивности / Сост. А. С. Мигунов. М.: Изд-во МГУ, 2001. С.167-173.

Пастернак Б. Высокая болезнь // Пастернак Б. Стихотворения и поэмы: В 2 т. Л.: Сов. писатель, 1990. Т. 1. С. 238-246.

Пацюков В. Новаторы и архаисты // Философия наивности / Сост. А. С. Мигунов. М.: Изд-во МГУ, 2001. С. 36-41.

Пименова Ж. Наивный танец // Философия наивности / Сост. А. С. Мигунов. М.: Изд-во МГУ, 2001. С. 185-193.

Прокофьев В. Н. О трёх уровня художественной культуры Нового и Новейшего времени (к проблеме примитива в изобразительных искусствах) // Примитив и его место в художественной культуре Нового и Новейшего времени. М.: Наука, 1983. С. 6-28.

Рабинович В. Видеть просто или просто видеть? // Философия наивности / Сост. А. С. Мигунов. М.: Изд-во МГУ, 2001. С. 42-71.

Рылёва А. Н., Балдина О. Д. Два взгляда на наивное искусство. СПб.: Дмитрий Буланин, 2011. 384 с.

Спивак М. Посмертная диагностика гениальности: Эдуард Багрицкий, Андрей Белый, Владимир Маяковский в коллекции Института мозга (материалы из архива Г. И. Полякова). М.: Аграф, 2001. 496 с.

Тарабаров С. К вопросу о термине «наивное искусство» // Философия наивности / Сост. А. С. Мигунов. М.: Изд-во МГУ, 2001. С. 203-206.

Цветаева М. И. Об искусстве. М.: Искусство, 1991. 479 с.

Юнг К. Г. К пониманию психологии архетипа младенца // Самосознание европейской культуры XX века: мыслители и писатели Запада о месте культуры в современном обществе. М.: Политиздат, 1991. С. 119-124. 